\title{
Revolution and Control of Fe-Al-(Mg, Ti)-O Oxide Inclusions in IF Steel during 260t BOF-RH-CC Process
}

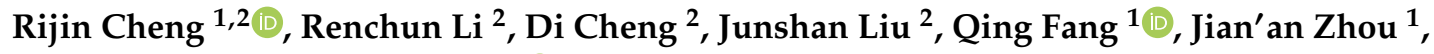 \\ Wenliang Dong ${ }^{3}$, Hua Zhang ${ }^{1, *}$ (D) and Hongwei $\mathrm{Ni}^{1}{ }^{1, *}$ \\ 1 The State Key Laboratory of Refractories and Metallurgy, Wuhan University of Science and Technology, \\ Wuhan 430081, China; chengrijin@wust.edu.cn (R.C.); qingfang@wust.edu.cn (Q.F.); \\ zhou_jianan@sina.com (J.Z.) \\ 2 Technical Center, HBIS Group Hansteel Company, Handan 056001, China; lirenchun@hbisco.com (R.L.); \\ Chengdi@hbisco.com (D.C.); liujunshan@hbisco.com (J.L.) \\ 3 Research Institute of Technology, Shougang Group Co., Ltd., Beijing 100043, China; \\ dongwenliang002@163.com \\ * Correspondence: huazhang@wust.edu.cn (H.Z.); nihongwei@wust.edu.cn (H.N.); \\ Tel.: +86-27-68862811 (H.Z. \& H.N.)
}

Received: 1 April 2020; Accepted: 16 April 2020; Published: 19 April 2020

\begin{abstract}
The evolution of inclusions that contain $\mathrm{Al}, \mathrm{Mg}$, and Ti was studied through industrial-grade experiments. Field emission scanning electron microscopy, energy dispersive spectrometry, inductively coupled plasma atomic emission spectrometry, and FactSage software were used to analyze the evolution mechanisms of inclusions in Al-killed titanium alloyed interstitial free (IF) steel. The research found that the evolution of inclusions during the smelting process of IF steel is results in 'large sphere-like $\mathrm{SiO}_{2}-\mathrm{CaO}-\mathrm{FeO}-\mathrm{MgO}-\mathrm{MnO}^{\prime}$ and 'small cluster spherical $\mathrm{FeO}-\mathrm{MnO}^{\prime}$ ' change to cluster-like $\mathrm{Al}_{2} \mathrm{O}_{3}$ and irregular $\mathrm{MgO} \cdot \mathrm{Al}_{2} \mathrm{O}_{3}$, then change to $\mathrm{Al}_{2} \mathrm{O}_{3} \cdot \mathrm{TiO}_{\mathrm{x}}$ and $\mathrm{Al}_{2} \mathrm{O}_{3}$, and finally change to $\mathrm{Al}_{2} \mathrm{O}_{3}$. It is difficult for $\mathrm{Al}_{2} \mathrm{O}_{3} \cdot \mathrm{TiO}_{x}$ to stably exist in the IF molten steel. It is the key to extend the holding time properly after Ruhrstahl Heraeus (RH) to ensure the removal of $\mathrm{Al}_{2} \mathrm{O}_{3}$ inclusion. With the increase of $\mathrm{Mg}$ content, the change path of $\mathrm{MgAl}_{2} \mathrm{O}_{4}$ inclusion in IF steel is that $\mathrm{Al}_{2} \mathrm{O}_{3}$ changes to $\mathrm{MgO} \cdot \mathrm{Al}_{2} \mathrm{O}_{3}$, and finally changes to $\mathrm{MgO}$. It is difficult to suppress $\mathrm{MgO} \cdot \mathrm{Al}_{2} \mathrm{O}_{3}$ spinel formation by controlling the oxygen in the steel, but Ca can modify part of the $\mathrm{MgO} \cdot \mathrm{Al}_{2} \mathrm{O}_{3}$ spinel inclusions during $\mathrm{RH}$ refining. In order to ensure the removal of $6-10 \mu \mathrm{m}$ inclusions, the holding time is suitable for $19-42 \mathrm{~min}$.
\end{abstract}

Keywords: IF steel; inclusion evolution; thermodynamics; $\mathrm{MgAl}_{2} \mathrm{O}_{4}$ inclusion; $\mathrm{Al}_{2} \mathrm{O}_{3} \cdot \mathrm{TiO}_{x}$

\section{Introduction}

Ultra-low carbon interstitial-free (IF) steel is widely used in automobile plate production because of its excellent deep draw ability and uniform mechanical properties. With the increasing quality requirements of cold rolling sheet, the control requirements of inclusions in ultra-low carbon steel are increasingly strict [1,2]. In the smelting process of ultra-low carbon IF steel, a certain amount of titanium, niobium, and other elements should be added, and the interstitial atoms, such as carbon and nitrogen, in ultra-low carbon steel should be completely fixed as carbon nitrogen compounds, so as to obtain clean ferritic steel without interstitial atoms [3]. According to the difference in the chemical composition of the inclusions, the inclusions in ultra-low carbon steel can be divided into $\mathrm{Al}_{2} \mathrm{O}_{3}$ inclusions, $\mathrm{Al}_{2} \mathrm{O}_{3}-\mathrm{TiO}_{x}$ inclusions, and $\mathrm{CaO}-\mathrm{Al}_{2} \mathrm{O}_{3}-\mathrm{MgO}$ inclusions [4-7]. Such inclusions can easily block immersion nozzles during continuous casting, and can also cause defects in the product. The study shows that $\mathrm{Al}_{2} \mathrm{O}_{3}-\mathrm{TiO}_{\mathrm{x}}$ inclusions are closely related to the clogging of the nozzle and the final product defect [8]. 
$\mathrm{Al}_{2} \mathrm{O}_{3}-\mathrm{TiO}_{x}$ inclusions are easily formed when the content of $\mathrm{FeO}$ is high [4], and the inclusions are unstable [6]. The [Al] and [Ti] react with the [O] from the self-dissociation of $\mathrm{SiO}_{2}$ in the slag and form inclusions changing from solid $\mathrm{Al}_{2} \mathrm{O}_{3}$ to $\mathrm{Al}_{2} \mathrm{O}_{3}-\mathrm{TiO}_{\mathrm{x}}$ inclusions. The inclusion chemistry composition is mainly dependent on the $w$ ([Al] ) and $w$ ([Ti]), while the number of inclusions can be reduced by increasing the ratios of $\mathrm{CaO}$ to $\mathrm{SiO}_{2}$ and $\mathrm{CaO}$ to $\mathrm{Al}_{2} \mathrm{O}_{3}$ in the slag [9]. Rare earth $\mathrm{Ce}$ is usually used to modify spinel inclusions in steel [10]. The irregular $\mathrm{Al}_{2} \mathrm{O}_{3}$ inclusions will be modified by the rare earth element $\mathrm{Ce}$ in Al-killed titanium-alloyed IF steel. The irregular $\mathrm{Al}_{2} \mathrm{O}_{3}$ inclusions of $10-15 \mu \mathrm{m}$ are wrapped by rare earth, and gradually transformed into spherical $\mathrm{CeAlO}_{3}, \mathrm{Ce}_{2} \mathrm{O}_{3}$, and $\mathrm{Ce}_{2} \mathrm{O}_{2} \mathrm{~S}$ inclusions of $5 \mu \mathrm{m}$, and finally dispersed into IF slabs [11].

When $\mathrm{T}[\mathrm{O}]$ in steel is reduced to $0.001 \%$, the spinel inclusions in molten steel become the most important factor affecting the purity of steel [12]. The $\mathrm{MgO} \cdot \mathrm{Al}_{2} \mathrm{O}_{3}$ spinel will be modified by $\mathrm{Ca}$ treatment. The inclusion modification route is $\mathrm{Al}_{2} \mathrm{O}_{3}$ change to $\mathrm{MgO} \cdot \mathrm{Al}_{2} \mathrm{O}_{3}$, and finally change to liquid complex inclusions [13]. $\mathrm{Mg}$ migrates to the molten steel and $\mathrm{MgAl}_{2} \mathrm{O}_{4}$ spinel inclusion is formed due to a reaction between $\mathrm{Mg}$ and $\mathrm{Al}_{2} \mathrm{O}_{3}$ inclusions. The spinel inclusion changes entirely into liquid oxide inclusion via the transfer of $\mathrm{Ca}$ from slag to metal. The modification reaction is more efficient as the $\mathrm{SiO}_{2}$ content in the slag decreases [14]. When the content of $\mathrm{Al}$ in steel is constant, with the increase of $\mathrm{Mg}$ content in steel, the inclusions in steel continuously precipitate $\mathrm{MgAl}_{2} \mathrm{O}_{4}$ spinel and finally changes into liquid $\mathrm{MgO}$ [15]. It is very important to control the content of $\mathrm{Mg}$ and $\mathrm{Al}$ in the alloy and to prevent the secondary oxidation of molten steel [16].

In summary, the inclusions have an important impact on the blockage of immersion nozzles and product quality of ultra-low carbon steel. In actual production, the molten steel in the basic oxygen furnace (BOF)-Ruhrstahl Heraeus (RH)-continuous casting (CC) process was sampled, and the characteristics, formation and evolution process, formation mechanism, and influencing factors of the inclusions were analyzed in detail to provide a theoretical basis for the control of inclusions in ultra-low carbon steel. Finally, the mechanical properties of DC06 IF steel were tested, and it was confirmed that the improved IF steel met the requirements of relevant steel grades. The experimental results have a complete understanding of the evolution process of inclusions in IF steel, provide guidance for the evolution and control of $\mathrm{MgO} \cdot \mathrm{Al}_{2} \mathrm{O}_{3}$ spinel inclusions and $\mathrm{MgO} \cdot \mathrm{TiO}_{\mathbf{x}}$ inclusions in steel, and put forward the process parameters to reduce the number and size of inclusions in steel. This is of great significance for improving the control level of non-metallic inclusions in automobile plate steel.

\section{Materials and Methods}

\subsection{Materials}

DC06 IF steel was produced by the $260 \mathrm{t}$ BOF-RH-Holding-CC process at the Hanbao steel plant. During tapping, $600 \mathrm{~kg}$ lime was added into the BOF, and $680 \mathrm{~kg}$ aluminum slag deoxidant was added onto the top slag after tapping. $\mathrm{RH}$ vacuum treatment includes decarburization, followed by aluminum deoxidization, then $338 \mathrm{~kg}$ Ti-Fe containing 70\% Ti alloying and keeping RH pure circulation time for 8-10 min. After RH treatment, molten steel remained unstirred in the ladle for $25-45$ min before casting. The standard for judging the chemical composition of DC06 IF steel is shown in Table 1.

Table 1. The standard for judging the chemical composition of IF steel, wt $\%$.

\begin{tabular}{ccccccccc}
\hline $\mathbf{C}$ & $\mathbf{S i}$ & $\mathbf{M n}$ & $\mathbf{P}$ & $\mathbf{S}$ & $\mathbf{A \mathbf { l } _ { \mathbf { s } }}$ & $\mathbf{T i}$ & $\mathbf{B}$ & $\mathbf{N}$ \\
\hline$\leq 0.0020$ & $\leq 0.010$ & $0.08-0.14$ & $\leq 0.012$ & $\leq 0.009$ & $0.020-0.050$ & $0.065-0.075$ & $0.0003-0.0008$ & $\leq 0.003$ \\
\hline
\end{tabular}

In order to investigate the evolution of inclusions in the IF steel smelting process, samples were taken by samplers of $\Phi 30 \mathrm{~mm} \times 10 \mathrm{~mm}$ during the industrial experiment steelmaking process, and the whole industrial experiments were carried out over 6 heats in total. A schematic diagram of charging and taking specimens during the steelmaking processes is shown in Figure 1. 


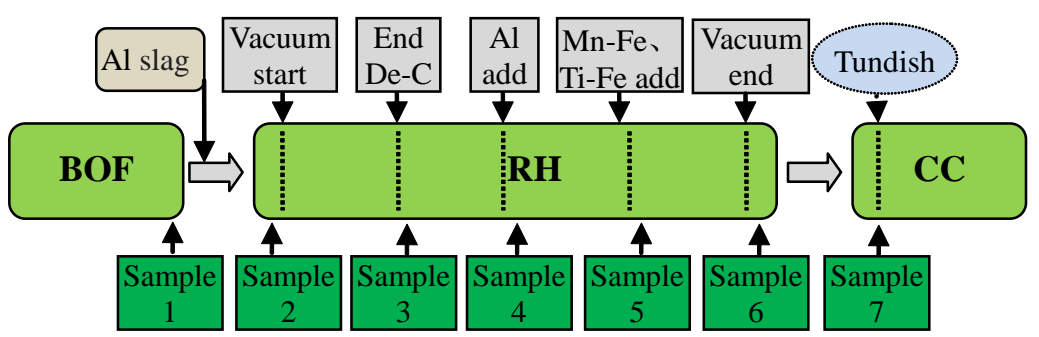

Figure 1. Schematic of charging and taking specimens during steelmaking processes.

\subsection{Mechanical Property Experiment}

During the tensile experiment, the DC06 IF steel coil transverse sample was taken, and the steel plate was processed into a dumbbell-shaped sample by using the Zwick 2Z50 (Ennepeta, Nordrhein-Westfalen, Germany) sample preparation machine. The initial gauge lengths of the tensile samples $\mathrm{l}_{0}$ and $\mathrm{b}_{0}$ are $80 \mathrm{~mm}$ and $20 \mathrm{~mm}$, respectively. Then the XKA714C (BYJC, Beijing, China) automatic numerical control machine was used to mill the edge of the sample to make it meet the standard GB/T228.1-2010. According to the inspection standard GB/T5213-2019, the Zwick automatic tensile testing machine (Model Z150robo Test L, Ennepeta, Nordrhein-Westfalen, Germany) was used to test the tensile test samples to obtain mechanical performance data, whereby 700 sets of tensile tests were carried out on DC06 IF steel, and the average value of mechanical properties was obtained.

\subsection{Methods of Chemical Analysis}

Each steel sample on the cross-sectional had been ground and polished by SiC papers and w1.5 diamond suspensions. The sample should be ground and polished in the way of transverse and longitudinal intersections, and inclusions of each steel sample were detected using FEI Nova NanoSEM400 (FEI, Hillsboro, OR, USA) scanning electron microscopy (SEM) coupled with energy-dispersive X-ray spectroscopy (EDS, FEI, Hillsboro, USA). The number, size, and chemical composition of inclusions were analyzed automatically using an ASPEX scanning electron microscope (ASPEX SEM, FEI, Delmont, PA, USA). The concentration of the $\mathrm{Al}, \mathrm{Ti}$, and $\mathrm{Ca}$ in steel was determined by IRIS advantage radial inductively coupled plasma atomic emission spectrometry (ICP-AES, Thermo Elemental, MA, USA). The [O] concentration in steel was measured online by a MSO-3690oxygen sensor (MINCO, Harland, WI, USA).

\section{Results and Discussion}

\subsection{Morphology and Evolution of Typical Non-Metallic Inclusions in Molten Steel}

Figure 2 shows the morphology and evolution of typical inclusions in molten steel. Sample 1 was taken from BOF before tapping. The morphology of inclusions before tapping is shown in Figure 2a. Inclusions in $\mathrm{BOF}$ steel are spherical. The inclusions in the $\mathrm{BOF}$ process are $\mathrm{SiO}_{2}-\mathrm{CaO}-\mathrm{FeO}-\mathrm{MgO}-\mathrm{MnO}$ type multi-phase composite inclusions. Due to the deep decarburization by oxygen blowing in $\mathrm{BOF}$, the molten steel has strong oxidizability. Therefore, there are many cluster spherical FeO-MnO inclusions below $5 \mu \mathrm{m}$ in the molten steel, and other large sphere-like inclusions below $50 \mu \mathrm{m}$ are $\mathrm{SiO}_{2}-\mathrm{CaO}-\mathrm{FeO}-\mathrm{MgO}-\mathrm{MnO}$.

Sample 2 was taken from ladle before vacuum start. Figure $2 \mathrm{~b}$ shows typical inclusions in molten steel before vacuum start during $\mathrm{RH}$ refining. The spherical and lump inclusions in the steel further grow up and float up, and many $\mathrm{CaO}-\mathrm{SiO}_{2}-\mathrm{FeO}-\mathrm{Al}_{2} \mathrm{O}_{3}-\mathrm{MgO}-\mathrm{MnO}$ inclusions are in the $50 \mu \mathrm{m}$ size. Due to the addition of $\mathrm{Al}$ slag modifier, large particles of $\mathrm{Al}_{2} \mathrm{O}_{3}$ above $50 \mu \mathrm{m}$ appear in the steel.

Sample 3 was taken from ladle after decarburization. After decarburization by $\mathrm{RH}$ vacuum refining, typical inclusions in molten steel are shown in Figure 2c. Irregular FeO-MnO-MgO and $\mathrm{MgO}-\mathrm{Al}_{2} \mathrm{O}_{3}$ inclusions combine to form approximately $15 \mu \mathrm{m}$ spherical inclusions or irregular FeO-MnO-MgO and $\mathrm{CaO}-\mathrm{Al}_{2} \mathrm{O}_{3}-\mathrm{FeO}-\mathrm{SiO}_{2}$ inclusions combine to form approximately $50 \mu \mathrm{m}$ nearly spherical inclusions. 
Large inclusions have been partially removed, and the single $\mathrm{Al}_{2} \mathrm{O}_{3}$ has been combined with other inclusions to form complex inclusions.

Sample 4 was taken from ladle after adding aluminum. Typical inclusions in molten steel after adding aluminum for 2 min are shown in Figure 2d. After decarburization in the RH refining process, aluminum is added to the molten steel for deep deoxidization. Due to the reaction between aluminum and oxygen, a large number of cluster-like or coral-like $\mathrm{Al}_{2} \mathrm{O}_{3}$ inclusions are generated by reaction (1). In addition, the inclusions in the steel aggregate and grow, and the lump $\mathrm{MgO} \cdot \mathrm{Al}_{2} \mathrm{O}_{3}$ spinel inclusions are wrapped by compact coral-like $\mathrm{Al}_{2} \mathrm{O}_{3}$ inclusions. Other Ca-based and Si-based inclusions are relatively rare after floating and removal.

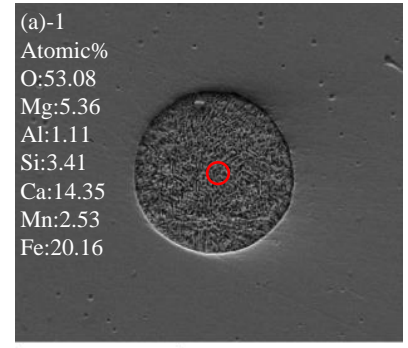

$50 \mu \mathrm{m}$

(a1)

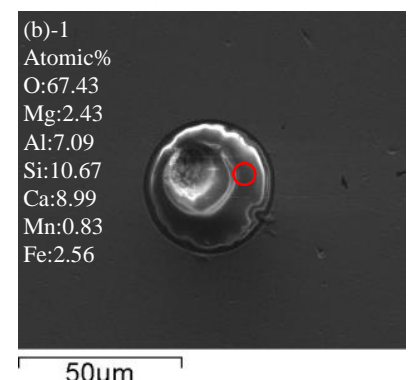

(b1)

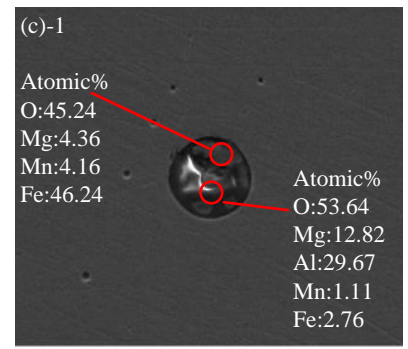

$20 \mu \mathrm{m}$

(c1)

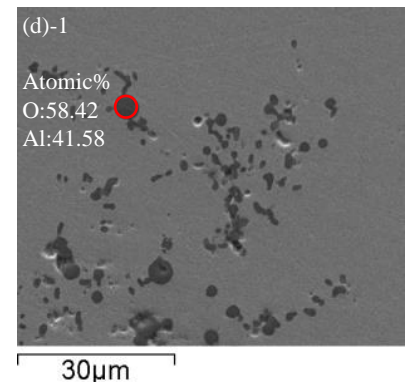

(d1)

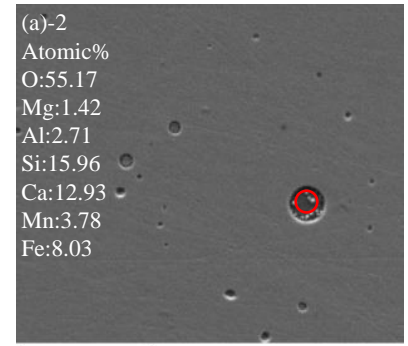

$20 \mu \mathrm{m}$

(a2)

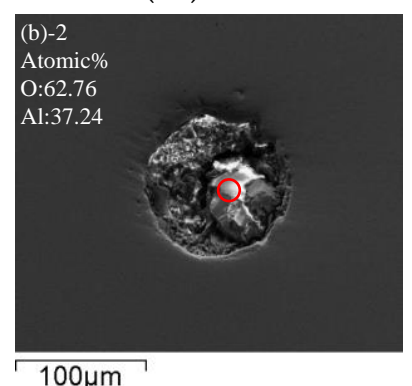

(b2)

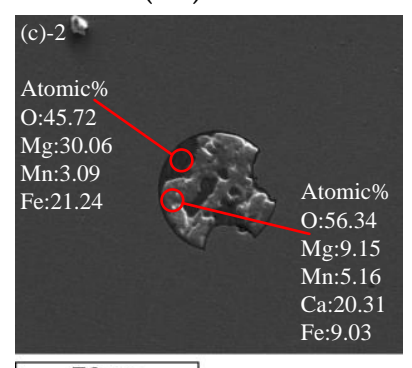

$70 \mu \mathrm{m}$

(c2)

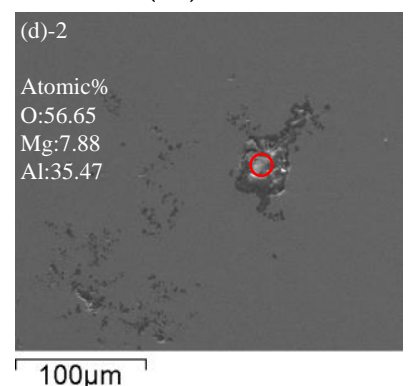

(d2)

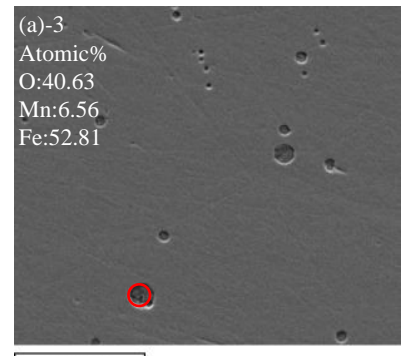

$20 \mu \mathrm{m}$

(a3)

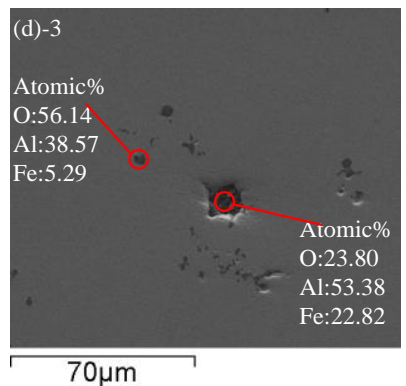

(d3)

Figure 2. Cont. 


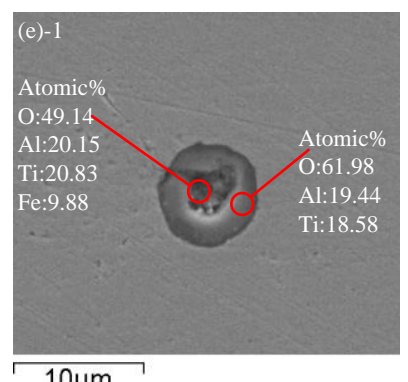

(e1)

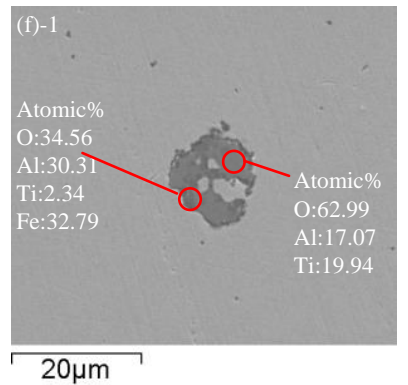

(f1)

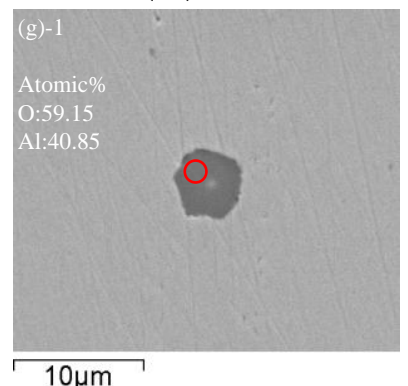

(g1)

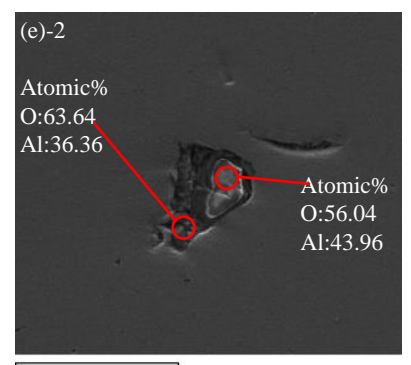

$50 \mu \mathrm{m}$

(e2)

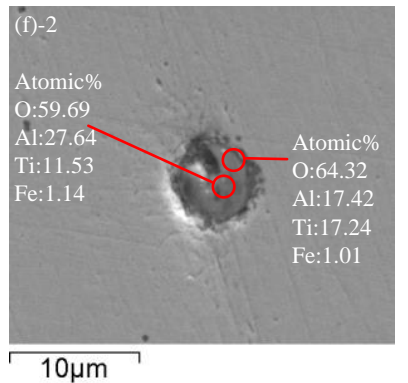

(f2)

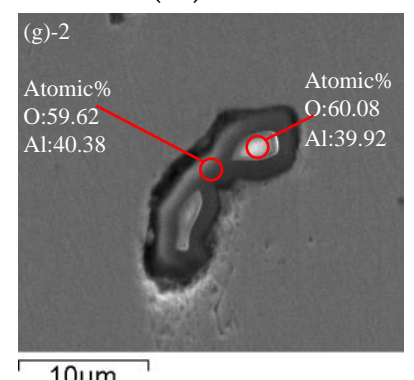

(g2)

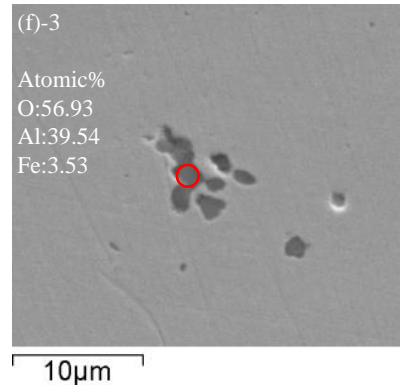

(f3)

Figure 2. Typical inclusions in molten steel: (a) Before tapping; (b) Before vacuum start; (c) After decarburization; (d) After adding aluminum for 2 min; (e) After adding titanium for 2 min; (f) After RH treatment; (g) From tundish.

$$
[\mathrm{Al}]+[\mathrm{O}]=\left(\mathrm{Al}_{2} \mathrm{O}_{3}\right)_{\text {inclusion }}
$$

Sample 5 was taken from ladle after adding titanium alloy. Figure 2e shows typical inclusions in molten steel after $\mathrm{RH}$ refining and adding titanium alloy. After adding aluminum for deoxidization during $\mathrm{RH}$ refining, a large number of cluster-like $\mathrm{Al}_{2} \mathrm{O}_{3}$ inclusions are generated in the steel. With the floating of $\mathrm{Al}_{2} \mathrm{O}_{3}$ inclusions, the total oxygen content in the steel is greatly reduced. Subsequently, after adding Ti-Fe alloying, some [Ti] reacts with [Al] and [O] by reaction (2) in the steel to form $\mathrm{Al}_{2} \mathrm{O}_{3} \cdot \mathrm{TiO}_{\mathrm{x}}$ inclusions below $10 \mu \mathrm{m}$, and a part of [Ti] reacts with [O] to generate $\mathrm{TiO}_{\mathrm{x}}$, and the $\mathrm{TiO}_{\mathrm{x}}$ inclusion wraps around the outside of the $\mathrm{Al}_{2} \mathrm{O}_{3}$ inclusions to produce irregular lump $\mathrm{Al}_{2} \mathrm{O}_{3} \cdot \mathrm{TiO}_{\mathrm{x}}$ inclusions by reaction (3).

$$
\begin{gathered}
{[\mathrm{Ti}]+[\mathrm{Al}]+[\mathrm{O}] \rightarrow\left(\mathrm{Al}_{2} \mathrm{O}_{3} \cdot \mathrm{TiO} X\right)_{\text {inclusion }}} \\
{[\mathrm{Ti}]+[\mathrm{O}]+\left(\mathrm{Al}_{2} \mathrm{O}_{3}\right)_{\text {inclusion }} \rightarrow\left(\mathrm{Al}_{2} \mathrm{O}_{3} \cdot \mathrm{TiO}_{\mathrm{X}}\right)_{\text {inclusion }}}
\end{gathered}
$$

Sample 6 was taken from ladle after RH treatment. After RH refining is completed, typical inclusions in molten steel are shown in Figure $2 \mathrm{f}$. At this time, large-scale $\mathrm{Al}_{2} \mathrm{O}_{3} \cdot \mathrm{TiO}_{\mathrm{x}}$ inclusions in the molten steel above $20 \mu \mathrm{m}$ have floated and removed, but there are still newly generated $\mathrm{Al}_{2} \mathrm{O}_{3} \cdot \mathrm{TiO}_{x}$ 
inclusions below $20 \mu \mathrm{m}$ in the molten steel, and $\mathrm{Al}_{2} \mathrm{O}_{3} \cdot \mathrm{TiO}_{\mathrm{x}}$ grows with $\mathrm{Al}_{2} \mathrm{O}_{3}$ as the core and wraps $\mathrm{Al}_{2} \mathrm{O}_{3}$, and the inclusions are mainly $\mathrm{Al}_{2} \mathrm{O}_{3} \cdot \mathrm{TiO}_{x}$, except for a few clusters of $\mathrm{Al}_{2} \mathrm{O}_{3}$ in the molten steel.

Sample 7 was taken from tundish during continuous casting. Figure $2 \mathrm{~g}$ shows typical inclusions in the molten steel of tundish. After the molten steel remains unstirred in the ladle for 25-45 min during the holding process, most of the large-particle $\mathrm{Al}_{2} \mathrm{O}_{3}$ inclusions have been removed by floating. Since the molten steel is sufficiently homogenized, the $\mathrm{Al}_{2} \mathrm{O}_{3} \cdot \mathrm{TiO}_{x}$ inclusions cannot stably exist in the steel, so the $\mathrm{Al}_{2} \mathrm{O}_{3} \cdot \mathrm{TiO}_{x}$ inclusions have decomposed into stable $\mathrm{Al}_{2} \mathrm{O}_{3}$ inclusions before entering the continuous casting mold, and Ti re-enters the molten steel. It can be proven from Figure $2 \mathrm{~g}$ that the inclusions in the final molten steel are mainly $\mathrm{Al}_{2} \mathrm{O}_{3}$. Therefore, it is key to ensure the quality of IF steel to extend the holding time properly after $\mathrm{RH}$ to ensure the removal of $\mathrm{Al}_{2} \mathrm{O}_{3}$ inclusions.

\subsection{Thermodynamics of Evolution and Control of Typical Oxide Inclusions during Refining}

The predominance area diagram of $\mathrm{Fe}-\mathrm{Al}-(\mathrm{Mg}, \mathrm{Ti})-\mathrm{O}$ system was calculated by using the thermodynamic software FactSage 7.0 (ThermFact Inc., Montreal, QC, Canada). The evolution and control of typical Fe-Al-(Mg, Ti)-O system inclusions in IF steel smelting process are analyzed by using these diagrams.

\subsubsection{Typical Spinel Inclusions in Molten Steel before RH Refining}

Figure 3 shows the predominance area diagram of the Fe-Al-Mg-O system with different oxygen contents at $1600{ }^{\circ} \mathrm{C}$. The Fe-Al-Mg-O system is used to study the $\mathrm{MgO}, \mathrm{MgAl}_{2} \mathrm{O}_{4}$ spinel and $\mathrm{Al}_{2} \mathrm{O}_{3}$ phase diagrams obtained from the change of $\mathrm{Al}$ content from $1 \times 10^{-6}$ to $1 \%$ and the change of $\mathrm{Mg}$ content from $0.1 \times 10^{-6}$ to $100 \times 10^{-6}$. When the $\mathrm{Mg}$ content is lower than the critical line of the $\mathrm{Al}_{2} \mathrm{O}_{3}$ and $\mathrm{MgO} \cdot \mathrm{Al}_{2} \mathrm{O}_{3}$ phases, an $\mathrm{Al}_{2} \mathrm{O}_{3}$ phase is formed. At this time, the $[\mathrm{Mg}]$ content in the molten steel is very low, and it is dissolved in the molten steel in the form of elemental $\mathrm{Mg}$. The $\mathrm{Mg}$ content is higher than the boundary line of $\mathrm{MgO} \cdot \mathrm{Al}_{2} \mathrm{O}_{3}$ and $\mathrm{MgO}$, and $\mathrm{Mg}$ exists as $\mathrm{MgO}$ inclusions phase.

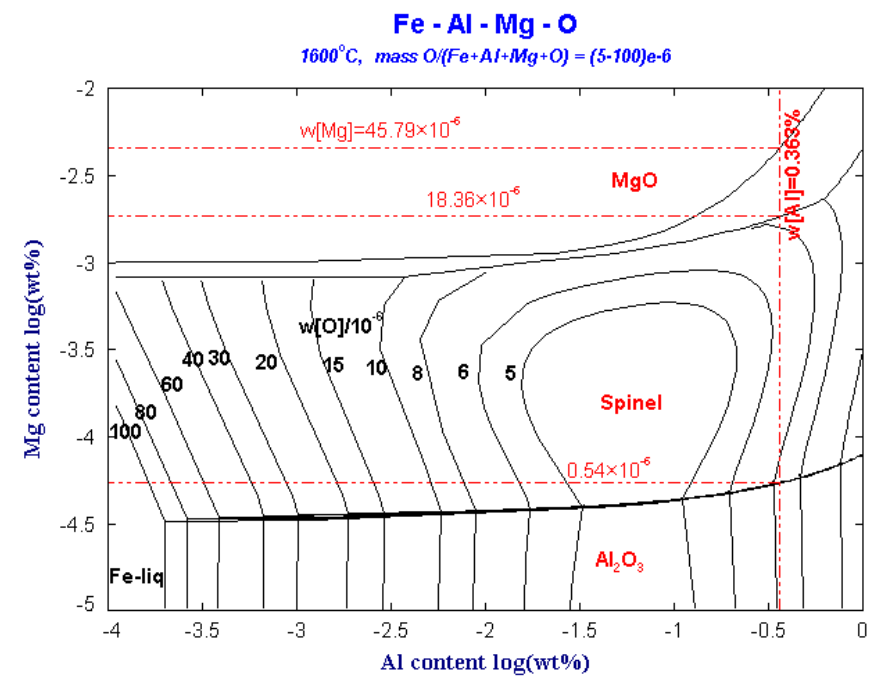

Figure 3. Predominance area diagram of Fe-Al-Mg-O system with different oxygen contents at $1600{ }^{\circ} \mathrm{C}$.

The steel samples were taken before $\mathrm{RH}$, after $\mathrm{RH}$, and in the tundish, and the samples were taken from six heats industrial experiment. The chemical compositions of $\mathrm{Al}, \mathrm{Ti}$, and $\mathrm{Ca}$ elements in the steel are analyzed, and the average compositions are shown in Table 2. 
Table 2. The average chemical compositions of $\mathrm{Al}, \mathrm{Ti}$, and $\mathrm{Ca}$ elements in the steel, $\mathrm{wt} \%$

\begin{tabular}{ccccc}
\hline Process & Al & Als & Ca & Ti \\
\hline Before RH & 0.472 & 0.363 & - & - \\
After RH & 0.044 & 0.042 & 0.0001 & 0.077 \\
Ladle holding & 0.036 & 0.033 & 0.0001 & 0.070 \\
\hline
\end{tabular}

The ladle slag is modified by Al slag modifier after tapping. Although the $\mathrm{Al}$ in the molten steel is about $0.363 \%$, the oxygen in the molten steel is still high. When the content of $\mathrm{Mg}$ in the molten steel is $0.54 \times 10^{-6}, \mathrm{MgAl}_{2} \mathrm{O}_{4}$ can stably exist in the steel. When the $\mathrm{Mg}$ content in the steel is greater than $18.36 \times 10^{-6}, \mathrm{Mg}$ will coexist as $\mathrm{MgAl}_{2} \mathrm{O}_{4}$ and $\mathrm{MgO}$ inclusions. When the $\mathrm{Mg}$ content in the steel is larger than $45.79 \times 10^{-6}, \mathrm{Mg}$ exists only as $\mathrm{MgO}$ inclusion. Therefore, as long as the $\mathrm{Mg}$ concentration in the molten steel is $(0.54-45.79) \times 10^{-6}$, the $\mathrm{MgAl}_{2} \mathrm{O}_{4}$ spinel inclusions will exist in the molten steel.

\subsubsection{Typical Mg-Al Spinel Inclusions in Molten Steel after RH Refining}

Figure 4 shows the predominance area diagram of Fe-Al-Mg-Ca-O system with $1 \times 10^{-6} \mathrm{Ca}$ and different oxygen contents at $1600^{\circ} \mathrm{C}$. As can be seen from Figure 4, when the content of [Mg] is fixed, the type of inclusions generated in the molten steel is always fixed within a certain range regardless of the change in the [Al] content. Therefore, in the Fe-Al-Mg-O-Ca molten steel system, the type of inclusions is mainly affected by the [Mg] content. In addition, as the [O] content in the molten steel increases, the range of $\mathrm{Al}$ corresponding to the formation of $\mathrm{MgAl}_{2} \mathrm{O}_{4}$ spinel and $\mathrm{Al}_{2} \mathrm{O}_{3}$ phases increases. In other words, the probability of forming brittle inclusions such as $\mathrm{MgO} \cdot \mathrm{Al}_{2} \mathrm{O}_{3}$ spinel and $\mathrm{Al}_{2} \mathrm{O}_{3}$ increases with increase the [O] content in the steel. However, it is difficult to suppress $\mathrm{MgO} \cdot \mathrm{Al}_{2} \mathrm{O}_{3}$ spinel formation by controlling the oxygen in the steel.

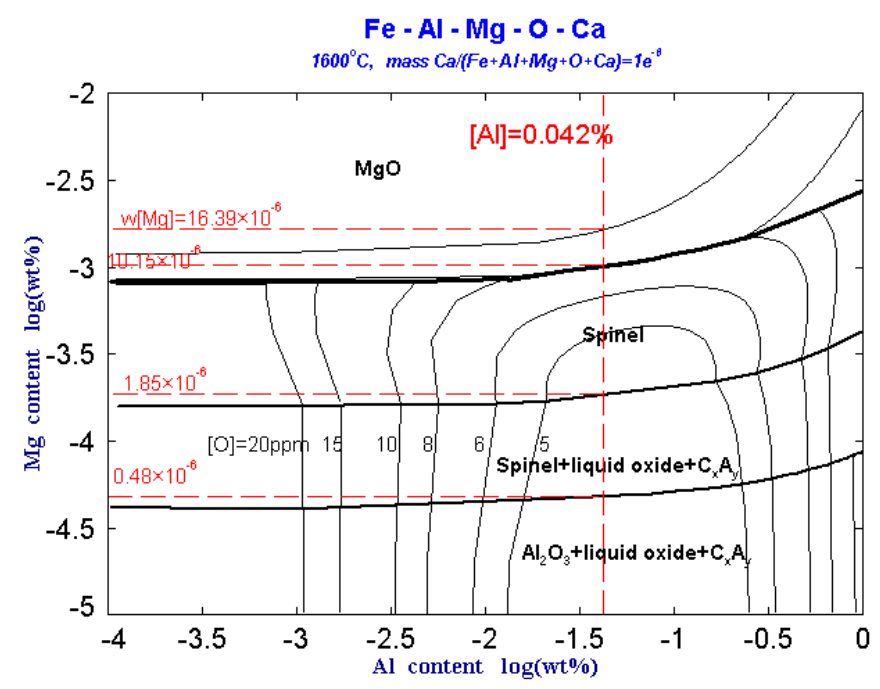

Figure 4. Predominance area diagram of Fe-Al-Mg-Ca-O system with $1 \times 10^{-6} \mathrm{Ca}$ and different oxygen contents at $1600{ }^{\circ} \mathrm{C}$.

In the Figure 4, 'liquid oxide' represents $\mathrm{CaO}-\mathrm{Al}_{2} \mathrm{O}_{3}-\mathrm{MgO}$ series liquid inclusions, and ' $\mathrm{C}_{x} \mathrm{~A}_{y}$ ' represents $(\mathrm{CaO})_{x}\left(\mathrm{Al}_{2} \mathrm{O}_{3}\right)_{y}$. When $1 \times 10^{-6}[\mathrm{Ca}]$ is added to the molten steel, the $\mathrm{MgO} \cdot \mathrm{Al}_{2} \mathrm{O}_{3}$ spinel area is significantly reduced, a part of the $\mathrm{MgO} \cdot \mathrm{Al}_{2} \mathrm{O}_{3}$ spinel area is replaced by the 'liquid oxide', and the original $\mathrm{Al}_{2} \mathrm{O}_{3}$ phase area is also replaced by a part of the 'liquid oxide'.

For the IF steel containing $0.042 \% \mathrm{Al}$ after $\mathrm{RH}$ refining in this experiment, when the content of [Mg] in the steel is less than $0.48 \times 10^{-6}, \mathrm{Mg}$ is dissolved in the molten steel and the inclusions in the molten steel are $\mathrm{Al}_{2} \mathrm{O}_{3}$ and $\mathrm{C}_{x} \mathrm{~A}_{y}$ type calcium aluminates. The overall area ratio is larger than that without $\mathrm{Ca}$. When content of $[\mathrm{Mg}]$ in steel increases to $0.48 \times 10^{-6}, \mathrm{MgO} \cdot \mathrm{Al}_{2} \mathrm{O}_{3}$ spinel inclusions begin to generate in the molten steel and it also contains $\mathrm{Al}_{2} \mathrm{O}_{3}$ and $\mathrm{C}_{x} \mathrm{~A}_{y}$ type calcium aluminates. 
When the content of $[\mathrm{Mg}]$ in the molten steel increases to $1.85 \times 10^{-6}$, the Al-containing inclusions in the molten steel all exist as $\mathrm{MgO} \cdot \mathrm{Al}_{2} \mathrm{O}_{3}$ spinel. As the content of $[\mathrm{Mg}]$ in the molten steel increases to $10.15 \times 10^{-6}$, the inclusions in the molten steel include $\mathrm{MgO}$ inclusions besides $\mathrm{MgO} \cdot \mathrm{Al}_{2} \mathrm{O}_{3}$ spinel. When the content of $[\mathrm{Mg}]$ in the molten steel increases to $16.39 \times 10^{-6}$, the $\mathrm{Mg}$-containing inclusions in the molten steel all exist as $\mathrm{MgO}$.

\subsubsection{Typical Al-Ti Inclusions in Molten Steel after RH Refining}

Figure 5 shows the predominance area diagram of Fe-Al-Ti-O system with different oxygen contents at $1600{ }^{\circ} \mathrm{C}$. It can be seen from the figure that $\mathrm{Al}_{2} \mathrm{O}_{3}$ can remain stable in the molten steel. When the content of [O] in steel is less than $10 \times 10^{-6}$, in addition to the [Al] and [Ti] dissolved in the molten steel, other trace $\mathrm{Al}$ and $\mathrm{Ti}$ in the steel are stable in the form of $\mathrm{Al}_{2} \mathrm{O}_{3}$ and $\mathrm{Ti}_{3} \mathrm{O}_{5}$, and $\mathrm{Al}_{2} \mathrm{O}_{3} \cdot \mathrm{TiO}_{\mathrm{x}}$ will not be stable in the molten steel.

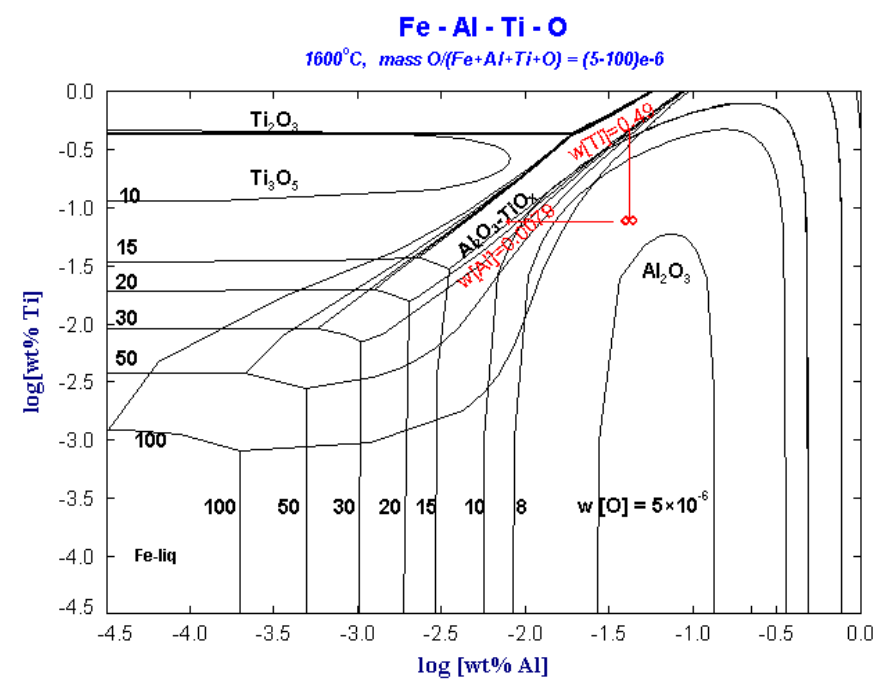

Figure 5. Predominance area diagram of Fe-Al-Ti-O system with different oxygen contents at $1600{ }^{\circ} \mathrm{C}$.

When the [O] content in steel increases to $10 \times 10^{-6}$, the stable region of $\mathrm{Al}_{2} \mathrm{O}_{3}$ increases. However, Ti exists as $\mathrm{Ti}_{2} \mathrm{O}_{3}$ instead of $\mathrm{Ti}_{3} \mathrm{O}_{5}$. As the dissolved [O] in steel increases above $15 \times 10^{-6}, \mathrm{Al}_{2} \mathrm{O}_{3}$ may react with $\mathrm{Ti}$ or $\mathrm{TiO}_{\mathrm{x}}$ by reaction (3) or (4) to form $\mathrm{Al}_{2} \mathrm{O}_{3} \cdot \mathrm{TiO}_{\mathrm{x}}$.

$$
[\mathrm{Ti}]+\left(\mathrm{Al}_{2} \mathrm{O}_{3}\right)_{\text {inclusion }} \rightarrow\left(\mathrm{Al}_{2} \mathrm{O}_{3} \cdot \mathrm{TiO}_{\mathrm{x}}\right)_{\text {inclusion }}+[\mathrm{Al}]
$$

It can be seen from the phase diagram that $\mathrm{Al}_{2} \mathrm{O}_{3} \cdot \mathrm{TiO}_{\mathrm{x}}$ may exist in steel in three situations: (1) when the dissolved [O] in the molten steel is up to $15 \times 10^{-6}$. (2) When the local Ti concentration in the molten steel is up to $0.49 \%$ during the titanium alloying adjusting process. (3) When the local $\mathrm{Al}$ concentration in the molten steel is as low as $0.0079 \%$. As the dissolved oxygen in ultra-low carbon steel is low, the Al-Ti inclusions in the ultra-low carbon steel liquid cannot exist stably. When the composition of $\mathrm{Al}$ and $\mathrm{Ti}$ in the steel liquid is uniform, the $\mathrm{Al}-\mathrm{Ti}$ inclusions will react with the $\mathrm{Al}$ in the steel continuously to form $\mathrm{Al}_{2} \mathrm{O}_{3}$ inclusions.

\subsubsection{Typical Al-Mg Inclusions in Tundish Molten Steel}

The average [O] content in the six experimental heats steel dropped to $3.9 \times 10^{-6}$ before Ti adding, but the $[\mathrm{O}]$ content increases to $10 \times 10^{-6}$ after $\mathrm{RH}$ refining. In order to understand the transformation process of $\mathrm{MgO} \cdot \mathrm{Al}_{2} \mathrm{O}_{3}$ spinel, the predominance area diagram of inclusions in $\mathrm{Fe}-\mathrm{Al}-\mathrm{Mg}-\mathrm{O}$ system with $[\mathrm{O}]=10 \mathrm{ppm}$ and $[\mathrm{Ca}]=1 \mathrm{ppm}$ at $1600{ }^{\circ} \mathrm{C}$ is shown in Figure 6. 


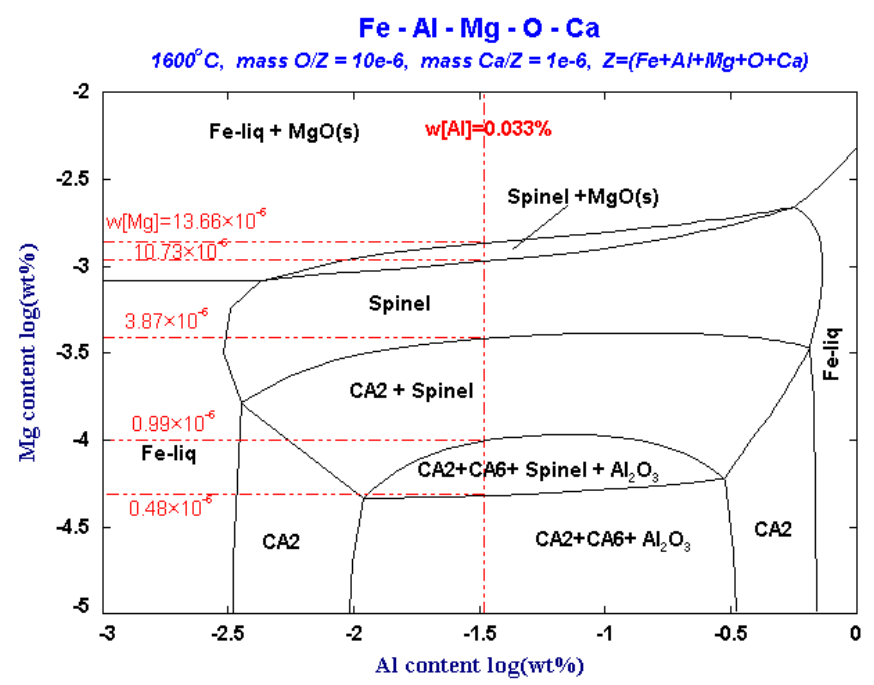

Figure 6. Phase diagram of inclusions in Fe-Al-Mg-O system with $[\mathrm{O}]=10 \mathrm{ppm}$ and $[\mathrm{Ca}]=1 \mathrm{ppm}$ at $1600^{\circ} \mathrm{C}$.

As can be seen from Figure 6, in the Fe-Al-Mg-O system, when the content of $[\mathrm{O}]$ and $[\mathrm{Al}]_{\mathrm{S}}$ in the steel is $10 \times 10^{-6}$ and $0.033 \%$, respectively, $\mathrm{MgO}$ and $\mathrm{MgO} \cdot \mathrm{Al}_{2} \mathrm{O}_{3}$ and $\mathrm{Al}_{2} \mathrm{O}_{3}$ inclusions will be precipitated separately with the difference in $\mathrm{Mg}$ content. If $[\mathrm{Mg}]$ content is less than $0.48 \times 10^{-6}$ in the steel, $\mathrm{Al}_{2} \mathrm{O}_{3}, \mathrm{CA}_{2}$, and $\mathrm{CA}_{6}$ inclusions will be precipitated in the molten steel. If [Mg] content increases to $0.48 \times 10^{-6}$, that is, the critical line of the $\mathrm{Al}_{2} \mathrm{O}_{3}$ and $\mathrm{MgO} \cdot \mathrm{Al}_{2} \mathrm{O}_{3}$ phases, $\mathrm{MgO} \cdot \mathrm{Al}_{2} \mathrm{O}_{3}$ spinel begins to precipitate in the molten steel. At this time, $[\mathrm{Mg}]$ and $\mathrm{Al}_{2} \mathrm{O}_{3}$ inclusions in the molten steel react to form $\mathrm{MgO} \cdot \mathrm{Al}_{2} \mathrm{O}_{3}$ spinel at the boundary between the $\mathrm{Al}_{2} \mathrm{O}_{3}$ phase and the $\mathrm{MgO} \cdot \mathrm{Al}_{2} \mathrm{O}_{3}$ phase. As the $\mathrm{Mg}$ content increase to $0.99 \times 10^{-6}, \mathrm{Al}_{2} \mathrm{O}_{3}$ will be transformed to $\mathrm{MgO} \cdot \mathrm{Al}_{2} \mathrm{O}_{3}$, and the $\mathrm{CA}_{6}$ phase will disappear. When $[\mathrm{Mg}]$ content reaches to $3.87 \times 10^{-6}, \mathrm{Al}_{2} \mathrm{O}_{3}$ will be completely transformed into $\mathrm{MgO} \cdot \mathrm{Al}_{2} \mathrm{O}_{3}$ spinel, and the $\mathrm{CA}_{2}$ phase will disappear. When $[\mathrm{Mg}]$ content continues to increase to $10.73 \times 10^{-6}, \mathrm{MgO}$ begins to precipitate in the molten steel. When the content $\mathrm{Mg}$ increases to $13.66 \times 10^{-6}$, the spinel is completely transformed to $\mathrm{MgO}$. With the increase of $\mathrm{Mg}$ content, the change path of inclusions is that $\mathrm{Al}_{2} \mathrm{O}_{3}$ change to $\mathrm{MgO} \cdot \mathrm{Al}_{2} \mathrm{O}_{3}$, and finally change to $\mathrm{MgO}$.

\subsection{Change and Control of Inclusions during Refining and Holding Time}

After the RH deoxidization is completed, the histogram of the change in the number of inclusions in the molten steel at different times is shown in Figure 7. The number, size, and chemical composition of inclusions were analyzed automatically by using ASPEX SEM. As can be seen from Figure 7, the number of inclusions reaches a maximum after $4 \mathrm{~min}$ of aluminum deoxidization, which indicates that within $4 \mathrm{~min}$, the oxygen in aluminum and steel reacts quickly to form $\mathrm{Al}_{2} \mathrm{O}_{3}$ inclusions. When aluminum is added for 4-8 $\mathrm{min}$, the removal rate of inclusions floating up is greater than the rate of generation, and the total number of inclusions in molten steel decreases, especially the number of inclusions larger than $10 \mu \mathrm{m}$. Therefore, in order to ensure that the inclusions generated by deoxidization are fully floated and removed, the pure circulation time after alloying should be greater than $8 \mathrm{~min}$.

After RH refining, the change of the number of inclusions in the molten steel with holding time is shown in Figure 8. It can be seen that the number of inclusions in the molten steel decreases with the extension of the holding time within $20 \mathrm{~min}$, especially the number of large particle inclusions above $10 \mu \mathrm{m}$ decreases to $1 \mathrm{~mm}^{-2}$, and $\mathrm{Al}_{2} \mathrm{O}_{3} \cdot \mathrm{TiO}_{\mathrm{x}}$ also decreases to $1 \mathrm{~mm}^{-2}$. 


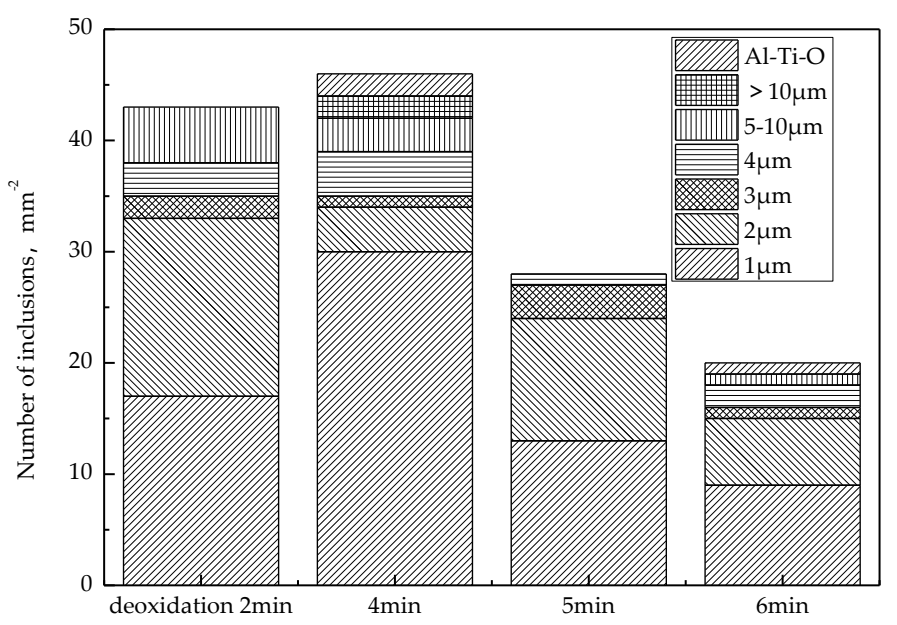

Figure 7. Change of inclusions after RH deoxidization.

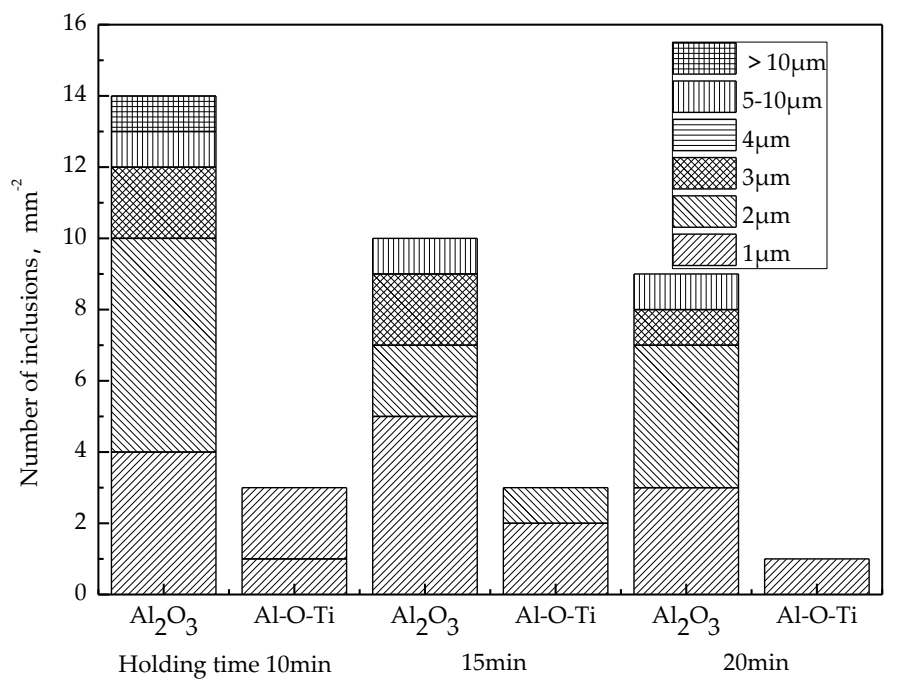

Figure 8. Change of inclusions during holding time.

Inclusions float in the molten steel in the way of Stokes to the surface of the ladle. If the time required to reach the top of the molten steel is less than the average residence time of the molten steel, the inclusions can be floated to the top of the molten steel and removed from the molten steel [17].

The floating velocity of inclusions in the still molten steel can be calculated using the Stokes settlement Formula (5).

$$
V_{\mathrm{s}}=\mathrm{g} d^{2}\left(\rho_{1}-\rho_{2}\right) /(18 \eta)
$$

where $V_{s}$ is the floating velocity of the inclusions, $\mathrm{cm} / \mathrm{s} ; \mathrm{g}$ is the acceleration of gravity, $\mathrm{m} / \mathrm{s}^{2} ; d$ is the diameter of the inclusions, $\mathrm{mm} ; \rho_{1}$ is the density of the molten steel, $\rho_{1}=7.0 \mathrm{~g} / \mathrm{cm}^{3} ; \rho_{2}$ is the density of the inclusions, $\rho_{2}=3.5 \mathrm{~g} / \mathrm{cm}^{3} ; \eta$ is molten steel viscosity, $\eta=0.05 \mathrm{~g} / \mathrm{cm} \cdot \mathrm{s}$ at $1600{ }^{\circ} \mathrm{C}$.

It can be seen from the above formula that the floating speed of inclusions is proportional to the square of the diameter of the inclusions, so large inclusions are easy to float. Substituting the data gives:

$$
V_{\mathrm{s}}=0.00381 \times d^{2}
$$

The depth of molten steel in this ladle is about $3.5 \mathrm{~m}$, and the floating time of inclusions can be calculated by Equation (7), and the result is shown in Figure 9. 


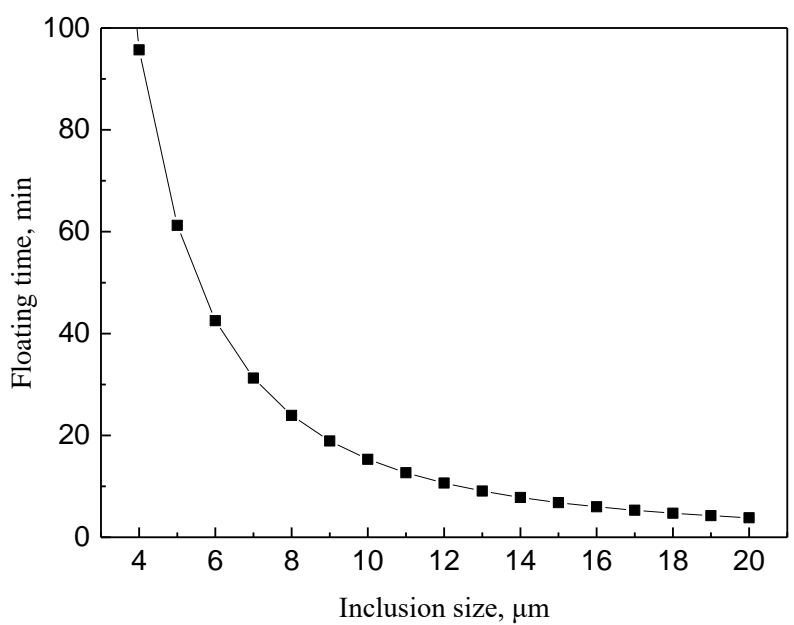

Figure 9. The relationship between the particle size and the time of inclusion floating up.

$$
t=350 /\left(0.00381 \times d^{2}\right)
$$

It can be seen from Figure 9 that inclusions with particle size less than $6 \mu$ m need about 42 min to float up. When smaller inclusions aggregate into inclusions with a particle size greater than $9 \mu \mathrm{m}$, they can float up and remove within about $19 \mathrm{~min}$, so the holding time should be 19-42 $\mathrm{min}$.

\subsection{Mechanical Properties of IF Steel}

The results of the DC06 IF steel mechanical properties test and requirements (GB/T 5213-2019) are shown in Table 3. According to Table 3, the yield strength $R_{p 0.2}$, tensile strength $R_{m}$, elongation after fracture $A_{80}$, tensile strain hardening index $N_{90}$, and plastic strain ratio $R_{90}$ of DC06 IF steel are $138.7 \mathrm{MPa}$, 304.7 $\mathrm{MPa}, 45.3 \%, 0.24$, and 2.91, respectively. Compared with standard values of GB/T5213-2019, the mechanical properties of DC06 IF steel meet the requirements.

Table 3. Mechanical properties of DC06 IF steel.

\begin{tabular}{|c|c|c|c|c|c|}
\hline $\begin{array}{l}\text { Standard and } \\
\text { Experiment }\end{array}$ & $\begin{array}{l}\text { Yield Strength } \\
R_{p 0.2}, \mathrm{MPa}\end{array}$ & $\begin{array}{c}\text { Tensile Strength } \\
R_{m}, \mathrm{MPa}\end{array}$ & $\begin{array}{l}\text { Elongation after } \\
\text { Fracture } A_{80}, \%\end{array}$ & $\begin{array}{c}\text { Tensile Strain } \\
\text { Hardening Index } N_{90}\end{array}$ & $\begin{array}{l}\text { Plastic Strain } \\
\text { Ratio } R_{90}\end{array}$ \\
\hline GB/T 5213-2019 & $\leq 170$ & $260-330$ & $\geq 42$ & $\geq 0.22$ & $\geq 2.1$ \\
\hline Experimental data & 138.7 & 304.7 & 45.3 & 0.24 & 2.91 \\
\hline
\end{tabular}

\section{Conclusions}

1. The IF steel inclusions in the $\mathrm{BOF}$ process are large sphere-like $\mathrm{SiO}_{2}-\mathrm{CaO}-\mathrm{FeO}-\mathrm{MgO}-\mathrm{MnO}$ multi-phase composite inclusions below $50 \mu \mathrm{m}$ and cluster spherical FeO-MnO inclusions below $5 \mu \mathrm{m}$. With the addition of Al-slag modifier and Al deoxidizer, a large amount of cluster-like or coral-like $\mathrm{Al}_{2} \mathrm{O}_{3}$ inclusions are formed. Moreover, $\mathrm{MgO} \cdot \mathrm{Al}_{2} \mathrm{O}_{3}$ spinel inclusions reduce gradually. $\mathrm{Al}_{2} \mathrm{O}_{3} \cdot \mathrm{TiO}_{\mathrm{x}}$ inclusions begin to form after Ti addition, and $\mathrm{Al}_{2} \mathrm{O}_{3}$-type inclusions increase slightly. During the holding process, the inclusions are removed and the number of $\mathrm{Al}_{2} \mathrm{O}_{3}$ inclusions and $\mathrm{Al}_{2} \mathrm{O}_{3} \cdot \mathrm{TiO}_{\mathrm{x}}$ inclusions in the steel is greatly reduced. In addition, $\mathrm{Al}_{2} \mathrm{O}_{3} \cdot \mathrm{TiO}_{\mathrm{x}}$ inclusions are larger in size compared to $\mathrm{Al}_{2} \mathrm{O}_{3}$ inclusions. After the molten steel remains unstirred in the ladle during the holding process, most of the large-particle $\mathrm{Al}_{2} \mathrm{O}_{3}$ inclusions have been removed by floating. In the tundish, the inclusions of $\mathrm{Al}_{2} \mathrm{O}_{3} \cdot \mathrm{TiO}_{x}$ in the molten steel disappear, and only $\mathrm{Al}_{2} \mathrm{O}_{3}$ inclusions remain in the end. It is key to extend the holding time properly after $\mathrm{RH}$ to ensure the removal of $\mathrm{Al}_{2} \mathrm{O}_{3}$ inclusion.

2. The predominance area diagram of Fe-Al-Mg-O system show that, when the $\mathrm{Mg}$ concentration in the molten steel before $\mathrm{RH}$ is $(0.54-45.79) \times 10^{-6}$, the $\mathrm{MgAl}_{2} \mathrm{O}_{4}$ spinel inclusions will exist in the molten steel. The type of inclusions is mainly affected by the $[\mathrm{Mg}]$ content, and it is difficult to 
suppress $\mathrm{MgO} \cdot \mathrm{Al}_{2} \mathrm{O}_{3}$ spinel formation by controlling the oxygen in the steel. When Ca content in steel is $1 \times 10^{-6}$, Ca can modify part of the $\mathrm{MgO} \cdot \mathrm{Al}_{2} \mathrm{O}_{3}$ spinel inclusions during $\mathrm{RH}$ refining, and the amount of $\mathrm{Mg}$ required to form spinel is reduced to $(0.48-16.39) \times 10^{-6}$. With the increase of $\mathrm{Mg}$ content, the change path of inclusions in IF steel is that $\mathrm{Al}_{2} \mathrm{O}_{3}$ change to $\mathrm{MgO} \cdot \mathrm{Al}_{2} \mathrm{O}_{3}$, and finally change to $\mathrm{MgO}$.

3. $\mathrm{Al}_{2} \mathrm{O}_{3} \cdot \mathrm{TiO}_{x}$ will not be stable in the IF molten steel, except for three situations: (1) when the dissolved $[\mathrm{O}]$ in the molten steel is up to $15 \times 10^{-6}$. (2) When the local Ti concentration in the molten steel is up to $0.49 \%$ during the titanium alloying adjusting process. (3) When the local $\mathrm{Al}$ concentration in the molten steel is as low as $0.0079 \%$.

4. In order to ensure the removal of 6-10 $\mu \mathrm{m}$ inclusions, the holding time is suitable for $19-42 \mathrm{~min}$.

5. The yield strength $R_{p 0.2}$, tensile strength $R_{m}$, elongation after fracture $A 80$, tensile strain hardening index $\mathrm{N}_{90}$, and plastic strain ratio $\mathrm{R}_{90}$ of DC06 IF steel are $138.7 \mathrm{MPa}, 304.7 \mathrm{MPa}, 45.3 \%, 0.24$, and 2.91, respectively. The mechanical properties of DC06 IF steel meet the requirements.

Author Contributions: R.C.: project administration, conceptualization, investigation, methodology, data curation, writing-original draft preparation. D.C.: Investigation. Q.F.: writing-review and editing. R.L.: project administration. J.L.: investigation, project administration. J.Z.: formal analysis. W.D.: visualization, drawing. H.Z.: funding acquisition, methodology, writing-review and editing. H.N.: conceptualization, supervision. All authors have read and agreed to the published version of the manuscript.

Funding: This research was funded by the financial support provided by the Open Youth Fund of State Key Laboratory of Refractories and Metallurgy, Wuhan University of Science and Technology (Grant No. 2018QN03) and and the National Natural Science Foundation of China (51774217).

Conflicts of Interest: The authors declare no conflicts of interest.

\section{References}

1. Tian, Y.; An, L.Q.; Jian, L.Z.; Mao, Y.; Guo, M.; Wang, P.; Li, Z.; Wen, T.G. Process analysis and practice of clean IF steel production. J. Iron Steel Res. Int. 2011, 18, 399-405.

2. Yuan, P.; Li, H.B.; Chen, B.; Zhu, K.R.; Pei, X.W.; Jiang, J.R. Control technology of surface sliver defects for automobile steel sheets. J. Iron Steel Res. 2017, 29, 800-806.

3. Sui, Y.F.; Sun, G.D.; Zhao, Y.; Wang, C.G.; Guo, M.; Zhang, M. Evolution of titaniferous inclusions in IF steelmaking. J. Univ. Sci. Technol. Beijing 2014, 36, 1174-1182.

4. Wang, R.; Bao, Y.P.; Li, Y.H.; Li, T.Q.; Chen, D. Effect of slag composition on steel cleanliness in interstitial-free steel. J. Iron Steel Res. Int. 2017, 24, 579-585. [CrossRef]

5. Shu, H.F.; Liu, L.; Liu, X.H.; Zhang, X.F. Investigation on variation of inclusions and total oxygen in IF steel after RH deoxidization. J. Iron Steel Res. Int. 2011, 18, 347-351.

6. Qin, Y.M.; Wang, X.H.; Li, L.P.; Huang, F.X. Effect of Oxidizing Slag on Cleanliness of IF Steel during Ladle Holding Process. Steel Res. Int. 2015, 86, 1037-1045. [CrossRef]

7. Yuan, P.; Zhang, J.; Liu, D.Z.; Li, H.B.; Zhu, K.R.; Chen, B. Formation mechanism and control technology of Al-Ti inclusions in ultra low carbon steel. Iron Steel 2018, 53, 24-30.

8. Park, D.C.; Jung, I.H.; Rhee, P.C.H.; Lee, H.G. Reoxidation of Al-Ti containing steels by $\mathrm{CaO}-\mathrm{Al}_{2} \mathrm{O}_{3}-\mathrm{MgO}_{-}-\mathrm{SiO}_{2}$ slag. ISIJ Int. 2004, 44, 1669-1678. [CrossRef]

9. Ren, Y.; Zhang, L.F.; Zhang, Y. Modeling reoxidation behavior of Al-Ti-containing steels by $\mathrm{CaO}-\mathrm{Al}_{2} \mathrm{O}_{3}-\mathrm{MgO}-\mathrm{SiO}_{2}$ slag. J. Iron Steel Res. Int. 2018, 25, 146-156. [CrossRef]

10. Yu, Z.; Liu, C.J. Modification mechanism of spinel inclusions in medium manganese steel with rare earth treatment. Metals 2019, 9, 804. [CrossRef]

11. Wang, R.; Bao, Y.P.; Yan, Z.J.; Li, D.Z.; Kang, Y. Comparison between the surface defects caused by $\mathrm{Al}_{2} \mathrm{O}_{3}$ and TiN inclusions in interstitial-free steel auto sheets. Int. J. Miner. Metall. Mater. 2019, 26, 178-185. [CrossRef]

12. Todoroki, H.; Mizuno, K. Effect of silica in slag on inclusion compositions in 304 stainless steel deoxidized with aluminum. ISIJ Int. 2004, 44, 1350-1357. [CrossRef]

13. Yang, S.F.; Li, J.S.; Wang, Z.F.; Li, J.; Lin, L. Modification of $\mathrm{MgO} \cdot \mathrm{Al}_{2} \mathrm{O}_{3}$ spinel inclusions in Al-killed steel by Ca treatment. Int. J. Miner. Metall. Mater. 2011, 18, 18-23. [CrossRef] 
14. Shin, J.H.; Par, J.H. Modification of Inclusions in Molten Steel by Mg-Ca Transfer from Top Slag: Experimental Confirmation of the 'Refractory-Slag-Metal-Inclusion (ReSMI)' Multiphase Reaction Model. Metall. Mater. Trans. B 2017, 48, 1-6. [CrossRef]

15. Cao, L.; Wang, G.C.; Yuan, X.H.; Jin, P.L.; Sridhar, S. Thermodynamics and agglomeration behavior on spinel inclusion in Al-deoxidized steel coupling with $\mathrm{Mg}$ treatment. Metals 2019, 9, 900. [CrossRef]

16. Chu, Y.P.; Chen, Z.Y.; Liu, N.; Zhang, L.F. Formation and control of spinel inclusions in high-speed heavy rail steel. Iron Steel 2020, 55, 38-46.

17. Wang, Y.; Cui, H.; Wang, W.; Yang, H. Effect of RH circulation time and holding time on cleanliness of IF steel. J. Iron Steel Res. 2017, 29, 649-653.

(C) 2020 by the authors. Licensee MDPI, Basel, Switzerland. This article is an open access article distributed under the terms and conditions of the Creative Commons Attribution (CC BY) license (http://creativecommons.org/licenses/by/4.0/). 